\title{
Biosynthetic Origins of the Isoprene Units of 4-Nerolidylcatechol in Potomorphe umbellata
}

\author{
Debora Cristina B. Bergamo ${ }^{a}$, Massuo Jorge Kato ${ }^{b}$, Vanderlan da S. Bolzani ${ }^{a}$ and Maysa Furlan $^{*, a}$ \\ ${ }^{a}$ Instituto de Química, Universidade Estadual Paulista, CP 355, 14801-970 Araraquara - SP, Brazil \\ ${ }^{b}$ Instituto de Química, Universidade de São Paulo, CP 26077, 05599-970 São Paulo - SP, Brazil
}

\begin{abstract}
A origem biossintética das unidades isoprênicas do 4-nerolidilcatecol (1), principal metabólito secundário de Potomorphe umbellata, foi investigada através da incorporação de glicose marcada com $\left[{ }^{14} \mathrm{C}\right]$ e $\left[{ }^{13} \mathrm{C}\right]$, e com precursores das vias mevalonoídica e triose/piruvato, incluindo mevalonolactona- $\left[2-{ }^{14} \mathrm{C}\right]$ e 3 -fosfato de gliceraldeído- $\left[\mathrm{U}-{ }^{14} \mathrm{C}\right]$, respectivamente. $\mathrm{O}$ padrão de incorporação de glicose-[1- $\left.{ }^{13} \mathrm{C}\right]$ em 1 foi determinado por experimentos de $\mathrm{RMN}{ }^{13} \mathrm{C}$ quantitativos. O padrão de marcação revelou que o precursor foi especificamente incorporado, e que as unidades isoprênicas presentes no 4-nerolidilcatecol são derivadas tanto do ácido mevalônico, quanto da via triose/piruvato. Os resultados também indicaram que tanto a via plastídica quanto citoplasmática são capazes de gerar unidades de difosfato de isopentenila para a biossíntese de $\mathbf{1}$.
\end{abstract}

The biosynthetic origins of the isoprene units of 4-nerolidylcatechol (1), the major constituent of Potomorphe umbellata, have been studied through feeding experiments with $\left[{ }^{14} \mathrm{C}\right]-$ and $\left[{ }^{13} \mathrm{C}\right]-$ glucose, and with precursors of the mevalonic acid and triose/pyruvate pathways, namely, $\left[2-{ }^{14} \mathrm{C}\right]$-mevalonolactone and $\left[\mathrm{U}-{ }^{14} \mathrm{C}\right]$-glyceraldehyde-3-phosphate, respectively. The pattern of incorporation of label from $\left[1-{ }^{13} \mathrm{C}\right]$-glucose into $\mathbf{1}$ was determined by quantitative ${ }^{13} \mathrm{C} \mathrm{NMR}$ spectroscopy. The labelling pattern revealed that the additive was specifically incorporated, and that the isoprene units of the sesquiterpenoid moiety of 4-nerolidylcatechol were derived from both the mevalonic acid and the triose/pyruvate pathways. The results indicate that both plastidic and cytoplasmic pathways are able to provide isopentenyl diphosphate units for the biosynthesis of $\mathbf{1}$.

Keywords: Potomorphe umbellata, Piperaceae, 4-nerolidylcatechol, biosynthesis, sesquiterpenoid, isopentenyl diphosphate

\section{Introduction}

The terpenoids represent one of the largest classes of secondary metabolites comprising, together with the steroids, more than 30,000 compounds to date. ${ }^{1}$ Whilst the terpenoids are known to play important roles in the development and survival of every living organism, ${ }^{2}$ many compounds of the class have been found to accumulate at high levels in a number of plant species. They possess, as a common building block, the isoprene unit that is formally derived from isopentenyl diphosphate (IPP). Originally, the well-studied mevalonic acid (MVA) pathway was considered to be the unique biosynthetic route to IPP and was believed to operate in all organisms. However, an alternative pathway has been shown to be involved in the formation of the hopane triterpenes in bacteria ${ }^{3}$ and, more

\footnotetext{
* e-mail: maysaf@iq.unesp.br
}

recently, the widespread occurrence of this route within the plant kingdom has been demonstrated..$^{4-8}$ The reaction sequence of the alternative pathway involves condensation of pyruvate and glyceraldehyde-3-phosphate leading to the formation of 1-desoxyxylulose-5-phosphate, the first $\mathrm{C}_{5}$ intermediate. Several subsequent steps, including an intramolecular rearrangement, lead to IPP. ${ }^{4}$

There is some reason to believe that the triose/pyruvate pathway is compartmentalised in the plastids of plant cells and is involved in the formation of mono-, di-, and tetraterpenoids, whilst the MVA pathway is located in the cytoplasm and is responsible for the synthesis of sesquiterpenes and sterols. ${ }^{9}$ However, substantial evidence indicates that this hypothesis of subcellular compartmentation of plant terpenoid biosynthesis may be simplistic as it does not take into account the exchange of plastidic and cytoplasmic metabolites. For example, early 
studies involving chamomile flowers (Chamomilla recutita) demonstrated an efficient incorporation of label from $\left[1-{ }^{13} \mathrm{C}\right]$-glucose into sesquiterpenes, but revealed an heterogeneous labelling pattern in the accumulated farnesyl pyrophosphate. Thus, whilst the two initial isoprene units clearly originated from the triose/pyruvate route, the third unit was derived from both the MVA and the triose/pyruvate pathways. ${ }^{10}$

The major constituent of leaves and roots of Potomorphe umbellata is the powerful antioxidant, 4-nerolidylcatechol (1). ${ }^{11,12}$ Currently, no information is available concerning the biosynthesis of either the sesquiterpene or the catechol portion of this type of compound. The aim of the present study was, therefore, to determine the route of formation of the $\mathrm{C}_{15}$ moiety of $\mathbf{1}$ in leaves of $P$. umbellate through feeding experiments involving appropriately labelled precursors. Determination of the ${ }^{13} \mathrm{C}$-enrichment pattern in $\mathbf{1}$ following the incorporation of label from $\left[1-{ }^{13} \mathrm{C}\right]$-glucose revealed that the sesquiterpene portion was derived from both the MVA and the triose/pyruvate pathways.

\section{Results and Discussion}

Labelled, putative precursors of the sesquiterpene portion of 4-nerolidylcatechol (1), namely, $\left[3-{ }^{14} \mathrm{C}\right]-R, S$ mevalonolactone and $\left[\mathrm{U}-{ }^{14} \mathrm{C}\right]$-glyceraldehyde-3-phosphate, were administrated to the leaves of Potomorphe umbellata, together with $\left[\mathrm{U}^{14} \mathrm{C}\right]$-glucose, which is a precursor of both mevalonolactone and glyceraldehyde-3-phosphate. Freshly harvested leaves were incubated, separately, with $2 \mu \mathrm{Ci}$ of each of these precursors for 6, 24, 48 and $72 \mathrm{~h}$, after which time the leaf material was extracted with ethanol and analysed by HPLC. Radiolabel from all precursors was incorporated into $\mathbf{1}$ (Table 1). Specific and/or non-specific incorporations of $\geq 1 \%$ were obtained within $72 \mathrm{~h}$ of feeding with $\left[3-{ }^{14} \mathrm{C}\right]-R, S$-mevalonolactone and $\left[\mathrm{U}-{ }^{14} \mathrm{C}\right]-$ glyceraldehyde-3-phosphate but, as would be expected, a considerably lower percentage incorporation $(0.1-0.3 \%)$ was attained with $\left[\mathrm{U}-{ }^{14} \mathrm{C}\right]$ - glucose.

In order to determine the specificity of incorporation, and hence the possible biosynthetic origin of the isoprenoid

Table 1. Percentage incorporations of activity from radiolabelled compounds into 4-nerolidylcatechol (1) by leaves of Potomorphe umbellata

\begin{tabular}{lccc}
\hline $\begin{array}{l}\text { Incubation } \\
\text { time (h) }\end{array}$ & $\begin{array}{c}{\left[3-{ }^{14} \mathrm{C}\right]-\text { Mevalono- }} \\
\text { lactone }\end{array}$ & $\begin{array}{c}{\left[\mathrm{U}-{ }^{14} \mathrm{C}\right]-} \\
\text { Glyceraldehyde } \\
\text {-3-phosphate }\end{array}$ & $\begin{array}{c}{\left[\mathrm{U}-{ }^{14} \mathrm{C}\right]-\mathrm{D}-} \\
\text { Glucose }\end{array}$ \\
\hline 6 & 0.2 & 0.6 & 0.1 \\
24 & 0.6 & 0.7 & 0.2 \\
48 & 0.7 & 0.9 & 0.2 \\
72 & 1.0 & 1.2 & 0.3 \\
\hline
\end{tabular}

moieties, experiments involving the incorporation of $\left[1-{ }^{13} \mathrm{C}\right]$-glucose into 4-nerolidylcatechol (1) were carried out. Different patterns of ${ }^{13} \mathrm{C}$-enrichment in $\mathbf{1}$ would be expected depending on the pathway followed..$^{10,13,14}$ Thus, the conversion of $\left[1-{ }^{13} \mathrm{C}\right]$-glucose into IPP via the MVA pathway would lead to the incorporation of label at positions 2,4 and 5 of each isoprene unit. On the other hand, if [1${ }^{13} \mathrm{C}$ ]-glucose is converted into pyruvate, the resulting $\mathrm{C}_{5}$ units derived from the triose/pyruvate pathway should be labelled at positions 1 and 5 (Figure 1). Whichever of the two pathways is extant, no label should appear at position 3 of any of the isoprene units if $\left[1-{ }^{13} \mathrm{C}\right]$-glucose is specifically incorporated into $\mathbf{1}$.

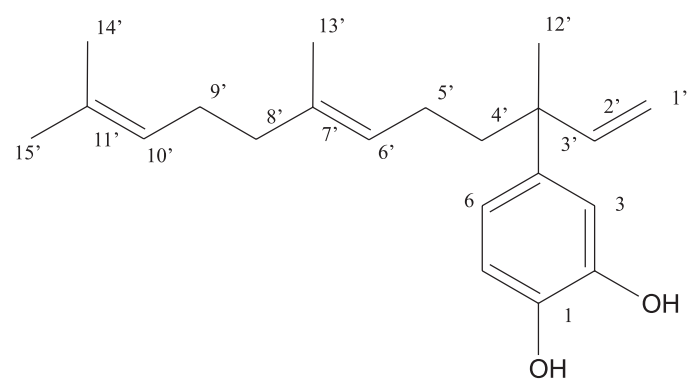

4-nerolidylcatechol (1)

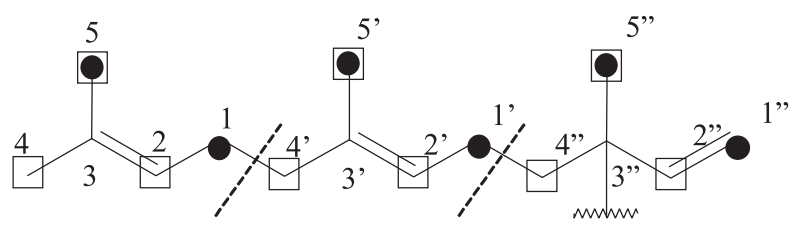

Figure 1. Predicted labelling patterns in the sesquiterpenoid moiety of 4-nerolidylcatechol following incorporation of $\left[1{ }^{13} \mathrm{C}\right]$-D-glucose according to the mevalonic acid pathway $\square$, and to the triose/pyruvate pathway

In feeding experiments involving $\left[1{ }^{13} \mathrm{C}\right]$-glucose as a putative precursor, eight young leaves of $P$. umbellata were fed for $72 \mathrm{~h}$ with $100 \mu \mathrm{L}$ of a $10 \%$ solution of $\left[1-^{13} \mathrm{C}\right]$ glucose, and then extracted with ethanol. The ethyl acetate soluble portion of the ethanol extract was fractioned by column chromatography over silica gel followed by TLC to afford 4-nerolidylcatechol (1). The ${ }^{13} \mathrm{C}$ NMR spectra of this sample of $\mathbf{1}$ and of 4-nerolidylcatechol at natural abundance sample were measured in $\mathrm{CDCl}_{3}$ under identical conditions. The relative abundances of ${ }^{13} \mathrm{C}$ at individual carbon atoms were calculated by comparison of the integration values for the peaks in the labelled sample with those in the natural abundance sample. The values were normalised to a reference value of $1.1 \%$ for ${ }^{13} \mathrm{C}$ abundance at the carbon with the lowest ${ }^{13} \mathrm{C}$ enrichment (Table 2). Enhancement of the signals was 
significant and varied in the range $2.9-6.9 \%$. Most importantly, no enrichment of the signals at C-3', C-7' or $\mathrm{C}-11$ ' of $\mathbf{1}$ was observed indicating that label was not incorporated into position 3 of any of the isoprene units (Figure 1). This demonstrates that the label from $\left[1-{ }^{13} \mathrm{C}\right]-$ glucose was incorporated specifically into $\mathbf{1}$, and not via catabolic processes followed by re-incorporation, within the time period of incubation. Furthermore, a significant enrichment of the remaining carbons (C-2, 4-6) was found (relative ${ }^{13} \mathrm{C}$ abundance of $1.5 \%$ ). This general labelling might be due to complex metabolic turnover of $\left[1-{ }^{13} \mathrm{C}\right]$ glucose with following statistical distribution of the carbon atoms in various positions of intermediates of carbohydrate metabolism.

As shown in Table 2, feeding experiment with $\left[1-{ }^{13} \mathrm{C}\right]-$ glucose resulted in clear enhancements of the signals at positions 1, 2, 4 and 5 of all of the isoprene units of the nerolidol moiety. Such a pattern of specific incorporation is consistent with the simultaneous operation of the MVA and triose/pyruvate pathways in the biosynthesis of the sesquiterpenoid portion of 4-nerolidylcatechol (1) in $P$. umbellata, and suggests an exchange of plastidic and cytoplasmic IPP units. These results corroborate previous studies $^{9}$ that provided evidence of significant differences in the degree of IPP exchange depending on the type and developmental stage of the tissue, thus giving rise to flexible compartmentalisation of terpenoid biosynthesis in plants.

Table 2. Percentage ${ }^{13} \mathrm{C}$ abundance in 4-nerolidylcatechol (1) isolated after incorporation of $\left[1-{ }^{13} \mathrm{C}\right]$-D-glucose in leaves of Potomorphe umbellata

\begin{tabular}{lcc}
\hline Carbon & $\delta(\mathrm{ppm})^{\mathrm{a}}$ & Relative enrichment $^{\mathrm{b}}(\%)$ \\
\hline C-1 & 141.3 & 1.1 \\
C-2 & 143.0 & 1.5 \\
C-3 & 114.8 & 1.1 \\
C-4 & 140.8 & 1.5 \\
C-5 & 119.0 & 1.5 \\
C-6 & 114.1 & 1.5 \\
C-1 & 111.4 & $\mathbf{3 . 3}$ \\
C-2' & 147.0 & $\mathbf{2 . 9}$ \\
C-3' & 43.7 & 1.1 \\
C-4' & 41.0 & $\mathbf{4 . 0}$ \\
C-5 & 23.1 & $\mathbf{5 . 1}$ \\
C-6' & 124.3 & $\mathbf{4 . 4}$ \\
C-7' & 134.9 & 1.1 \\
C-8' & 39.6 & $\mathbf{3 . 6}$ \\
C-9' & 26.6 & $\mathbf{3 . 3}$ \\
C-10' & 124.4 & $\mathbf{6 . 9}$ \\
C-11' & 131.2 & 1.1 \\
C-12' & 24.8 & $\mathbf{2 . 9}$ \\
C-13' & 15.8 & $\mathbf{4 . 0}$ \\
C-14' & 25.6 & $\mathbf{4 . 0}$ \\
C-15' & 17.6 & $\mathbf{4 . 7}$ \\
\hline
\end{tabular}

${ }^{\mathrm{a}}$ Referenced to $\mathrm{CDCl}_{3} ;{ }^{\mathrm{b}} \mathrm{Calculated}$ from comparison ${ }^{3}$ of relative intensities of signals in ${ }^{13} \mathrm{C}$ NMR spectra of labelled and unlabelled 4-nerolidylcatechol.

\section{Experimental}

\section{General}

$\left[3-{ }^{14} \mathrm{C}\right]-R, S$-Mevalonolactone $\left(100.5 \mu \mathrm{Ci} \mathrm{mL} \mathrm{mL}^{-1}\right)$ was purchased from Dupont, $\left[\mathrm{U}^{-14} \mathrm{C}\right]$-glyceraldehyde $(50.0$ $\left.\mu \mathrm{Ci} \mathrm{mL}^{-1}\right)$ and $\left[\mathrm{U}_{-}{ }^{14} \mathrm{C}\right]-\mathrm{D}$-glucose $\left(1000 \mu \mathrm{Ci} \mathrm{mL}^{-1}\right)$ were obtained from American Radiolabeled Chemicals, and $\left[1-{ }^{13} \mathrm{C}\right]$-D-glucose (99\%) was from Aldrich. All solvents were of reagent grade and redistilled prior to use. HPLC separations were performed on a Waters 991 system equipped with a photodiode array detector and a Supelco LC-18 reverse phase column (250 x $4.6 \mathrm{~mm}$ i.d.; $5 \mu \mathrm{m}$ ). The measurement of radioactivity was carried out using a Tri-Carb ${ }^{\circledR}$ model 2100TR liquid scintillation analyser. The ${ }^{13} \mathrm{C}$ NMR spectra of samples at natural abundance and ${ }^{13} \mathrm{C}$-labelled samples were measured under identical conditions $\left(125 \mathrm{MHz}, 26^{\circ} \mathrm{C}\right.$, repetition time $0.955 \mathrm{~s}, 45^{\circ}$ pulse angle) using a Varian Unity 500 spectrometer.

\section{Plant material}

Leaves of Potomorphe umbellata employed in the feeding experiments with ${ }^{14} \mathrm{C}$-labelled precursors were collected from plants grown under a $16 \mathrm{~h}$ day regime in greenhouses at the Institute of Biological Chemistry (WSU) in Pullman, USA. Plants used in experiments involving $\left[1-{ }^{13} \mathrm{C}\right]$-glucose were grown under a natural daynight regime in greenhouse at the Institute of Chemistry (UNESP) in Araraquara, Brazil.

\section{Administration of $\left[{ }^{14} \mathrm{C}\right]$-labelled compounds to leaves of P. umbellata}

Young leaves of $P$. umbellata were excised and fed for $6,24,48$ and $72 \mathrm{~h}$ with $100 \mu \mathrm{L}$ of a solution containing $2 \mu \mathrm{Ci}$ of either $\left[3-{ }^{14} \mathrm{C}\right]-R, S$-mevalonolactone, $\left[\mathrm{U}-{ }^{14} \mathrm{C}\right]$-glyceraldehyde-3-phosphate or $\left[\mathrm{U}-{ }^{14} \mathrm{C}\right]-\mathrm{D}$ glucose using one leaf for each feeding experiment. The leaf was frozen in liquid nitrogen, dried overnight under vacuum and extracted, with sonication, for 15 min with ethanol $(2 \times 10 \mathrm{~mL})$. The solvent was evaporated, the residue was resuspended in methanol $\left(1 \mathrm{mg} \mathrm{mL}^{-1}\right)$ and a $10 \mu \mathrm{L}$ aliquot analysed by HPLC (elution programme linear gradient of methanol : water from 65:35 to 85:15 in $10 \mathrm{~min}$, followed by isocratic elution with $85: 15$ for a further $10 \mathrm{~min}$; flow rate $-1 \mathrm{~mL} \mathrm{~min}{ }^{-1}$; detection - 280 $\mathrm{nm})$. Fractions $(1 \mathrm{~mL})$ of the eluate were collected over a 44 min period and submitted to liquid scintillation counting. 
Administration of $\left[1-{ }^{13} \mathrm{C}\right]-D$-glucose to leaves of $P$. umbellata

Eight young leaves (13.70 g) of P. umbellata were excised and fed for $72 \mathrm{~h}$ with $100 \mu \mathrm{L}$ of a $10 \%$ solution of $\left[1-{ }^{13} \mathrm{C}\right]-\mathrm{D}$-glucose. The leaves were frozen in liquid nitrogen and extracted, with sonication, for 15 min with ethanol $(2 \times 25 \mathrm{~mL})$. The solvent was evaporated and the extract $(0.52 \mathrm{~g})$ fractioned by partition between ethyl acetate and water. The ethyl acetate fraction $(0.20 \mathrm{~g})$ was applied to a column chromatography of silica gel (20.00 g; 230 - 400 mesh; Merck) and eluted with hexane containing increasing amounts of ethyl acetate (up to 50\%) to yield six fractions. The third and fourth fractions were combined, and the resultant residue $(0.09 \mathrm{~g})$ chromatographed on silica gel $\mathrm{GF}_{254}$ (Merck) TLC layers eluted with hexane:ethyl acetate (7:3) to yield 4-nerolidylcatechol (1) (0.03 g).

The ${ }^{1} \mathrm{H}$ and ${ }^{13} \mathrm{C}$ NMR spectra of $\mathbf{1}$ obtained from an incorporation experiment with $\left[1-{ }^{13} \mathrm{C}\right]$-glucose and reference sample of $\mathbf{1}$ from field-grown plants were recorded in $\mathrm{CDCl}_{3}$ under identical conditions with a VARIAN 500 spectrometer (relative to $\mathrm{CDCl}_{3}$ at $\delta_{\mathrm{H}} 7.24$ ppm and $\delta_{\mathrm{C}} 77.0 \mathrm{ppm}$ ). Evaluation of relative ${ }^{13} \mathrm{C}$ enrichment was made by calculation from the relative intensities of both spectra as reported for 4-nerolidylcatechol $(\mathbf{1}){ }^{3}$

\section{Acknowledgments}

This work was supported by grants provided by FAPESP (03/11524-9). MF, MJK and VSB are grateful to CNPq for fellowships, and DCBB wishes to thank FAPESP for the provision of scholarships. We also wish to acknowledge Dr. Norman G. Lewis for laboratory facilities in the feeding labelled experiments.

\section{References}

1. Rohdich, F.; Kis, K.; Bacher, A.; Eisenreich, W.; Curr. Opin. Chem. Biol. 2001, 5, 535.

2. Macgarvey, D. J.; Croteau, R.; Plant Cell 1995, 7, 1015.

3. Rohmer M.; Knani, M.; Simonin, P.; Sutter, B.; Sahm, H.; Biochem. J. 1993, 295, 517.

4. Rohmer, M.; Seemann, M.; Horbach, S.; Bringer-Meyer, S.; Sahm, H.; J. Am. Chem. Soc. 1996, 118, 2564.

5. Knöss, W.; Reuter, B.; Pharm. Acta Helv. 1998, 73, 45.

6. Asada, Y.; Li, W.; Yoshikawa, T.; Phytochemistry 2000, 55, 323.

7. Eisenreich, W.; Sagner, S.; Zenk, M. H.; Bacher, A.; Tetrahedron Lett. 1997, 38, 3889.

8. Schwender, J.; Seemann, M.; Lictenthaler, H. K.; Rohmer, M.; Biochem. J. 1996, 316, 73.

9. McCaskill, D.; Croteau, R.; Trends Biotechnol. 1998, 16, 349.

10. Adam, K-P.; Zapp, J.; Phytochemistry 1998, 48, 953.

11. Kijjoa, A.; Giesbrecht, A. M.; Akisue, M. K.; Gottlieb, O. R.; Gottlieb, H. E.; Planta Med. 1980, 39, 85.

12. Desmarchelier, C.; Barros, S.; Repetto, M.; Latorre, L. R.; Kato, M. J.; Cousiio, J.; Ciccia, G.; Planta Med. 1998, 63, 561.

13. Seto, H.; Watanabe, H.; Furihata, K.; Tetrahedron Lett. 1996, 37, 7979 .

14. Barlon, A. J.; Becker, H.; Adam, K. P.; Phytochemistry 2001, $57,7$.

Received: February 18, 2005 Published on the web: December 5, 2005

FAPESP helped in meeting the publication costs of this article. 